tember 4 he was in long. $155^{\circ} 28^{\prime}$ W., lat. $8^{\circ} 20$ N., sailed from Fanning's Island three days before. At $5 \mathrm{p} . \mathrm{m}$. noticed strange appearance in the sun, which was greenish. Strange colours over the west and around the sky at sunset. The sun was green at setting. Thought bad weather was portended. Never saw such appearances before.

Both parties are positive that the schooner was three days out when their fears were thus excited. She sailed September $\mathbf{r}$. No entry in ship's log of the above phenomena.

Honolulu, February 20

\author{
S. E. BISHOP
}

Another note relative to these phenomena:- " August 20, 1861. - Earthquake at Naples. At Castellamare the water is so discoloured, that although the calm has been complete, we fear some subterranean perturbation. The heat is intense. At the same time the atmosphere presented a very peculiar appearance. There are no clouds, and during the whole week a thick mist has enveloped the city and coast, and the sun when setting is as red as blood."-(Moniteur du 29 Août, 1861.)

Royal College of Science for Ireland, J. P. O'REILLY Stephen's Green, Dublin

\section{Meteorological Bibliography}

I REJOICE to see the well-earned tribute which you have paid to Dr. Hellmann's excellent " Repertorium der Deutschen Meteorologie," and as a worker in the same field I. trust that you will permit me to add that I agree with every word which your reviewer has said as to its excellence.

My object in writing is merely to point out that, thanks to the liberality of the United States Government, we may hope soon to have, not a perfect catalogue, but one which will be extremely useful, especially if, as I hope, the United States Government adopt my suggestion and endeavour to arrange with Dr. Hellmann for the incorporation of the first part of his "Repertorium" with the materials already forwarded to them.

Your reviewer is perfectly right in urging the absolute necessity of steps being taken to index and classify the multitudinous publications now appearing. Dr. Hellmann in his "Repertorium" says that 800 publications upon metcorology appear annually, or more than two each day, hence the impossibility of any one keeping abreast of the entire literature.

As regards the catalogue which I had the pleasure of sending to the United States last autunin, I annex an abstract of the description which I gave at the Southport mecting of the British Association in case you may think it of sufficient importance to be worthy of a place in NaTURE. Dr. Hellmann's "Repertorium" only reached me just before my catalogue was shipped, hence the absence of reference to it in the annexed paper.

62, Camden Square, N.W., April 4

G. J. Symons

On the Completion of the European Portion of the Preliminary Meteorological Catalogue, by G. F. Symons

The author commenced by giving a few illustrations of the large amount of time and energy which has been wasted by meteorologists, owing to their not knowing what had previously been done, sometimes even in their own country, but most frequently in other parts of the world; and he pointed out that with the modern development of meteorological work and of meteorological literature, some effort, upon a large scale, to deal with this evil was imperatively necessary.

Mr. Symons described the catalogue which he had formed during the last twenty or twenty-five years, by extracting (from many thousand catalogues issued by dealers in second-hand books in most of the capitals of Europe) all the titles of works on meteorology or kindred subjects. He also described the important publication, by the Royal Society, of its "Catalogue of Scientific Papers," and showed wherein the two agreed, and how largely each supplemented deficiencies in the other.

He then explained the steps which Prof. Cleveland Abbe had taken in preparing his card catalogue, and the arrangements whereby a copy of Mr. Symons's catalogue was to be prepared and forwarded to the United States for incorporation with Prof. Abbe's.

Mr. Symons then stated the additions which had been made to the original proposal, and that the following catalogues had been subsequently incorporated, each giving afproximately the number of titles set against it, viz. :-
Prof. A. Poëy's

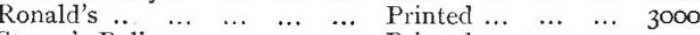

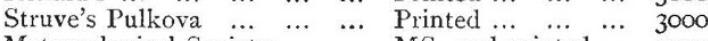

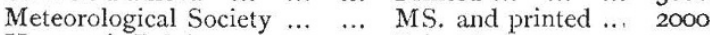

$\begin{array}{lllllll}\text { Houzeau's Belgian ... } & \ldots & \ldots & \text { Printed ... } & \ldots & \ldots & 2000\end{array}$

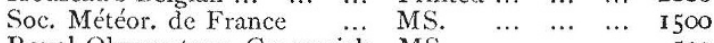

Royal Observatory, Greenwich $\begin{array}{llllll}\ldots S & & \ldots & \ldots & \ldots & 1500 \\ & & \ldots & \ldots & \ldots & 500\end{array}$

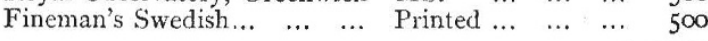

Total about $\quad \ldots \quad \ldots \overline{\mathrm{I} 8,500}$

Of course a great many of these were duplicates, but every catalogue contained titles which were not in any of the others, and altogether they have undoubtedly added very largely to the value of the work; it is impossible to state how largely, nor is it material in a case wherein the assistance rendered has been almost as great as the catalogue, and as diverse as the languages dealt with.

The precise number of titles forwarded is not known, but is probably about 20,000. Prof. Abbe's catalogue is understood to contain about ro,ooo, but probably there will be a few thousand common to both catalogues, and therefore the preliminary catalogue, which the United States Signal Office, under the direction of General FIazen, will proceed to prepare for publication, will probably contain the titles of more than 25,000 books and papers upon meteorology.

Mr. Symons remarked, in conclusion, that the catalogue must not be regarded as complete. It was impossible to make it perfect-it could not be perfect as regarded the past until every public and private library in the world had been searched. It could not be perfect for the present, because every day new works appeared in different parts of the world, and all could not be simultaneously inserted. Nor would his part of it bear bibliographical criticism, for he was not a bibliographical expert, and his chief aim had been to give information useful to working meteorologists.

\section{Ice Volcanoes-Mountain Rainbow}

THE past winter has been unusually cold and stormy in Ontario, and, as a result, an uneven strip of ice 100 to 200 yards wicle has accumulated along the lake shore, sometimes forming mounds twenty or thirty feet high. Many of these mounds are conical, and have a crater-like opening communicating with the water. In stormy weather cvery wave hurls a column of spray and ice fragments through the opening. The ejecta freeze fast as they fall, and add to the height of the cone. In high winds the coast seems fringed with miniature volcanoes in active eruption. After a time the crater becomes clogged with ice, and the volcano may be looked on as extinct. Often a second crater is formed just to seaward of the first, and growing upon its ruins.

Mr. J. A. Fleming mentions in your issue for January $3 I$ (p. 310) a circular rainbow seen from a hill-top against mist. I saw the same phenomenon three years ago near the Lofoden Islands, as a fog was breaking. It was noticed and admired by other passengers on the steamer also. Each saw his shadow enlarged upon the mist, and with the head surrounded by a brightly coloured halo or rainbow. The beautiful sight disappeared after a few minutes as the fog thickened again.

Faraday Hall, Victoria University, Cobourg, Canada

\section{Thread-twisting}

IN reply to "Cosmopolitan's" question in NATURE (vol. xxix. p. 525), I have been many years in Orkney, but do not remember to have seen the women twisting thread with "the palm of the hand on the thigh," but the fishermen therc twist the short lengths of horsehair line called "snoods," which when united together form fishing lines of different strengths, in this manner.

The women of the North- $\Lambda$ merican Indians always twist the short threads of sinew with which moccasins and leather clothes are sewn in this way: The sinew is torn up or divided into thin filaments slightly moistened by being drawn between the lips, then twisted between palm and thigh.

Kensington, April 5

In reply to "Cosmopolitan's" query as to the occurrence of the habit of thread-twisting with the palm of the hand on the 